\title{
Antimicrobial Activities of Some Pyrazoline and Hydrazone Derivatives
}

\section{Bazı Pirazolin ve Hidrazon Türevlerinin Antimikrobiyal Aktiviteleri}

\author{
(D) Begüm EVRANOS AKSÖZ1* ${ }^{\star}$ (D) Suna Sibel GÜRPINAR2, (D) Müjde ERYILMAZ2 \\ 1Süleyman Demirel University Faculty of Pharmacy, Department of Pharmaceutical Chemistry, Isparta, Turkey \\ 2Ankara University Faculty of Pharmacy, Department of Pharmaceutical Microbiology, Ankara, Turkey
}

\begin{abstract}
Objectives: Resistance to antibiotics is recognized as one of the biggest threats to human health worldwide. Frequent and unnecessary use of antibiotics has caused infectious agents to adapt to antibiotics and thus drugs have become less effective. The resistance to many antibiotics necessitates the discovery of new antibiotics. In this study, two new and 23 previously reported 2-pyrazoline derivatives and one hydrazone derivative were evaluated for their in vitro antibacterial and antifungal activities.

Materials and Methods: For the determination of the minimum inhibitory concentration (MIC) values of compounds, microbroth dilution was used. Results: The antimicrobial activities of the compounds were found in a wide range with MIC values of $32-512 \mu \mathrm{g} / \mathrm{mL}$.

Conclusion: The synthesized compounds showed moderate antimicrobial activity compared with the standards. They can be used as lead molecules for the synthesis of more effective compounds.
\end{abstract}

Key words: Synthesis, antimicrobial activity, pyrazoline derivatives, hydrazone derivatives

öz

Amaç: Antibiyotik direnci, dünya çapında insan sağlığına yönelik en büyük tehditlerden biri olarak kabul edilmektedir. Sık ve gereksiz antibiyotik kullanımı, bulaşıcı organizmaların antibiyotiklere adapte olmasına neden olarak ilaçların daha az etkili hale gelmesine yol açmıştır. Birçok antibiyotiğe karşı gelişen direnç, yeni antibiyotiklerin keşfini gerektirmektedir. Bu çalışmada, daha önce başka etkileri nedeni ile yayınlanmış 232 -pirazolin ve bir hidrazon türevi ile iki yeni 2-pirazolin türevi bileșiğin, in vitro antibakteriyel ve antifungal aktiviteleri incelenmiştir.

Gereç ve Yöntemler: Bileşiklerin minimum inhibitör konsantrasyon (MiK) değerlerinin belirlenmesi için mikrobroth dilüsyon yöntemi kullanıldı.

Bulgular: Bileşiklerin antimikrobiyal aktiviteleri, 32-512 $\mu \mathrm{g} / \mathrm{mL}$ MiK değerleri ile geniş bir aralıkta bulunmuştur.

Sonuç: Sentezlenen bileşikler, standartlarla karşılaştırıldıklarında orta düzeyde antimikrobiyal aktivite göstermiştir ve daha etkili bileșiklerin sentezi için öncü moleküller olarak kullanılabilecekleri sonucuna varılmıştır.

Anahtar kelimeler: Sentez, antimikrobiyal aktivite, pirazolin türevleri, hidrazon türevleri 


\section{INTRODUCTION}

Antimicrobials are drugs that kill or inhibit the growth of microorganisms. Resistance to antimicrobials occurs when microorganisms change in a way that reduces the effectiveness of drugs. Antibiotic resistance has become a major clinical and public health problem worldwide today. Resistance rates are rising dangerously in the world. New resistance mechanisms are emerging, making it difficult to treat infectious diseases.-4 In order to control this global problem, all government sectors and societies should take the necessary precautions and should support investigations on developing new antimicrobial drugs.

Hydrazones are formed as intermediates in the reaction of hydrazine and its derivatives with $\beta$-unsaturated carbonyl compounds but they are often not isolated due to their low stability and give pyrazolines with ring closure. ${ }^{5,6}$ These compounds have interesting biological properties, such as antimicrobial, antituberculous, antidepressant, analgesic, anticonvulsant, antitumor, antiviral, and antiinflammatory activities. ${ }^{7}$ Pyrazolines are five-membered and two neighboring nitrogen-containing heterocyclic compounds. They can be synthesized by the reaction of chalcones and hydrazines/hydrazides. ${ }^{8-10}$ Pyrazoline derivatives are electron-rich compounds that are thought to cause a wide variety of biological activities. Pyrazolines are important compounds because of their antimicrobial, analgesic, antiinflammatory, and antidepressant activities. ${ }^{11-13}$ According to the literature above, both pyrazoline and hydrazone compounds have antimicrobial activity. Therefore, we tested our compounds for their antimicrobial activity. In the present study, two new and 23 previously reported 2 -pyrazoline derivatives and one hydrazone derivative were tested for their antibacterial and antifungal activity.

\section{MATERIALS AND METHODS}

\section{Antimicrobial activity tests}

In the antibacterial activity tests, Staphylococcus aureus ATCC 29213, Bacillus subtilis ATCC 6633, Enterococcus faecalis ATCC 29212, Escherichia coli ATCC 25922, and Pseudomonas aeruginosa ATCC 27853 were used as test bacteria. For antifungal activity testing, Candida albicans ATCC 10231 was used. The cultures were prepared in Mueller Hinton Broth (Difco, Difco Laboratories, Detroit, MI, USA). For determination of minimum inhibitory concentration (MIC) values, microbroth dilution was used. ${ }^{14,15}$ Serial two-fold dilutions ranging from $1024 \mu \mathrm{g} / \mathrm{mL}$ to 8 $\mu \mathrm{g} / \mathrm{mL}$ were made in the medium. The incubation conditions for the bacteria were $18-24 \mathrm{~h}$ at $35 \pm 1{ }^{\circ} \mathrm{C}$ and for the fungi were 48 h at $35 \pm 1{ }^{\circ} \mathrm{C}$; the last well with no microbial growth was noted as the MIC value $(\mathrm{mg} / \mathrm{mL})$. Ampicillin, ofloxacin, and fluconazole were used as the positive control and $10 \%$ dimethyl sulfoxide (DMSO) was used as the negative control. All experiments were repeated three times. There was no statistical data analysis.

\section{Chemistry}

All compounds except compounds 20 and 24 have been reported earlier. ${ }^{10,13}$
Synthesis of chalcone derivatives $(A, B)$

2'-Hydroxy-4'-methoxy acetophenone/5'-chloro-2'-hydroxy acetophenone $(4.99 \mathrm{mmol})$ and 4-bromobenzaldehyde/4benzyloxybenzaldehyde $(4.99 \mathrm{mmol})$ were reacted in ethanol $(20 \mathrm{~mL})$ using $\mathrm{KOH}$ solution $(50 \% \mathrm{w} / \mathrm{v})$ in water $(5 \mathrm{~mL})$ as catalyzer at room temperature overnight. Ice was added to the mixture and $\mathrm{pH}$ was set to $3-4$ with $1 \mathrm{M} \mathrm{HCl}$. Then the mixture was filtered and crystallized from ethanol. ${ }^{16-18}$

(E)-3-(4-bromophenyl)-1-(2-hydroxy-4-methoxyphenyl)prop2-en-1-one (A): Yellow product. $61.14 \%$ yield. M.p. $141.0{ }^{\circ} \mathrm{C}$. [lit. 138.0-140.0 $\left.{ }^{\circ} \mathrm{C}\right] . .^{19} \mathrm{C}_{16} \mathrm{H}_{13} \mathrm{BrO}_{3}$.

(E)-3-(4-(benzyloxy)phenyl)-1-(5-chloro-2-hydroxyphenyl) prop-2-en-1-one (B): Orange product. $93.70 \%$ yield. M.p. 138.0 ${ }^{\circ} \mathrm{C}$. [lit. $100.0-102.0{ }^{\circ} \mathrm{C}$. ${ }^{20} \mathrm{C}_{22} \mathrm{H}_{17} \mathrm{ClO}_{3}$.

Synthesis of compounds 20 and 24

First, 1 equiv of compound $A /$ compound $B$ and 1 equiv of isoniazid were heated and stirred in ethanol $(20 \mathrm{~mL})$ for $4-25$ $\mathrm{h}$. Then the filtered products recrystallized from ethanol to give 20 and 24. $21-23$

(5-(4-(benzyloxy)phenyl)-3-(5-chloro-2-hydroxyphenyl)4,5-dihydropyrazol-1-yl)(pyridin-4-yl)methanone (20): Beige product. Yield: $24.8 \%$. M.p. $237.1{ }^{\circ} \mathrm{C}$. IR $\left(v, \mathrm{~cm}^{-1}\right): 3167(\mathrm{OH})$, 1641 (amide $\mathrm{C}=\mathrm{O}), 1585(\mathrm{C}=\mathrm{N}) .{ }^{1} \mathrm{H}$ NMR (DMSO- $\mathrm{d}_{6}, 400 \mathrm{MHz}$ ): $2.91\left(\mathrm{dd}, 1 \mathrm{H}, \mathrm{J}_{1}=16.4 \mathrm{~Hz}, \mathrm{~J}_{2}=12.4 \mathrm{~Hz}, \mathrm{H}_{\mathrm{A}}\right), 3.46\left(\mathrm{dd}, 1 \mathrm{H}, \mathrm{J}_{1}=3.2 \mathrm{~Hz}\right.$, $J_{2}=3.2 \mathrm{~Hz} \mathrm{H}$ ), 5.14 (s, $2 \mathrm{H},-\mathrm{OCH}_{2} \mathrm{Ph}$ ), 5.22 (dd, $1 \mathrm{H}, \mathrm{J}_{1}=2.4 \mathrm{~Hz}$, $\left.J_{2}=2.8 \mathrm{~Hz}, \mathrm{H}_{\mathrm{x}}\right), 7.02-8.74(16 \mathrm{H}$, aromatic $-\mathrm{H}), 11.11(\mathrm{~s}, 1 \mathrm{H}, \mathrm{OH}) . \mathrm{MS}$ (ESI): $\mathrm{m} / \mathrm{z}=484[\mathrm{M}+\mathrm{H}](100 \%) \cdot \mathrm{C}_{28} \mathrm{H}_{22} \mathrm{CIN}_{3} \mathrm{O}_{3} \cdot 1.25 \mathrm{H}_{2} \mathrm{O}: \mathrm{C} 66.36$, H 4.44, N 8.05; calcd. C 66.14, H 4.72, N 8.26.

(5-(4-bromophenyl)-3-(2-hydroxy-4-methoxyphenyl)-4,5dihydropyrazol-1-yl) (pyridin-4-yl)methanone (24): Cream colored product. Yield $29.5 \%$. M.p. $225.5{ }^{\circ} \mathrm{C}$. IR $\left(v, \mathrm{~cm}^{-1}\right): 3174$ $(\mathrm{OH}), 1641$ (amide $\mathrm{C}=\mathrm{O}$ ), $1576(\mathrm{C}=\mathrm{N}) .{ }^{1} \mathrm{H}$ NMR (DMSO-d, 400 $\mathrm{MHz}$ ): 2.82 (dd, $1 \mathrm{H}, J_{1}=12.4 \mathrm{~Hz}, J_{2}=12.8 \mathrm{~Hz}, \mathrm{H}_{\mathrm{A}}$ ), 3.41 (dd, $1 \mathrm{H}$, $\left.J_{1}=2.8 \mathrm{~Hz}, \mathrm{~J}_{2}=3.2 \mathrm{~Hz}, \mathrm{H}_{\mathrm{B}}\right), 3.79\left(\mathrm{~s}, 3 \mathrm{H},-\mathrm{OCH}_{3}\right), 5.29\left(\mathrm{dd}, 1 \mathrm{H}, \mathrm{J}_{1}=2.8\right.$ $\left.\mathrm{Hz}, \mathrm{J}_{2}=2.4 \mathrm{~Hz}, \mathrm{H}_{\mathrm{x}}\right), 6.59-8.73(11 \mathrm{H}$, aromatic $-\mathrm{H}), 11.02(\mathrm{~s}, 1 \mathrm{H}, \mathrm{OH})$. MS (ESI): $\mathrm{m} / \mathrm{z}=452[\mathrm{M}+\mathrm{H}], 454[\mathrm{M}+\mathrm{H}+2](100 \%) . \mathrm{C}_{22} \mathrm{H}_{18} \mathrm{BrN}_{3} \mathrm{O}_{3}$. $0.5 \mathrm{H}_{2} \mathrm{O}$ : C 57.15, H 4.38, N 9.36; calcd. C 57.23, H 4.12, N 9.10.

\section{RESULTS AND DISCUSSION}

A number of pyrazoline derivatives (compounds 2-26) and one hydrazone derivative (compound 1) were prepared. The structures of the target compounds are outlined in Figure 1.

Twenty-six compounds were tested for their antibacterial and antifungal activities. Antimicrobial activity was screened against two Gram-negative (E. coli ATCC 25922 and $P$. aeruginosa ATCC 27853) and three Gram-positive (S. aureus ATCC 29213, E. faecalis ATCC 29212, and B. subtilis ATCC 6633) bacteria and a fungus (C. albicans ATCC 10231) using ampicillin, ofloxacin, and fluconazole as the standard drugs. The results are given in Table 1.

Compound 1, the hydrazone, showed moderate activity against all the bacteria and the fungus. Pyrazoline derivatives were found to possess moderate activity against the bacteria and fungus. Whether the ring was open (hydrazone) or closed 
Table 1. In vitro antimicrobial activities of hydrazone (1) and 2-pyrazoline (2-26) derivatives

\begin{tabular}{|c|c|c|c|c|c|c|}
\hline \multirow{3}{*}{ Compound } & \multicolumn{6}{|c|}{ MIC values of test microorganisms $(\mu \mathrm{g} / \mathrm{mL})$} \\
\hline & \multicolumn{2}{|c|}{ Gram-negative bacteria } & \multicolumn{3}{|l|}{ Gram-positive bacteria } & \multirow{2}{*}{$\begin{array}{l}\text { Fungus } \\
\text { Candida albicans } \\
\text { ATCC } 10231\end{array}$} \\
\hline & $\begin{array}{l}\text { Escherichia coli } \\
\text { ATCC } 25922\end{array}$ & $\begin{array}{l}\text { Pseudomonas aeruginosa } \\
\text { ATCC } 27853\end{array}$ & $\begin{array}{l}\text { Staphylococcus aureus } \\
\text { ATCC } 29213\end{array}$ & $\begin{array}{l}\text { Enterococcus faecalis } \\
\text { ATCC } 29212\end{array}$ & $\begin{array}{l}\text { Bacillus subtilis } \\
\text { ATCC } 6633\end{array}$ & \\
\hline 1 & 256 & 128 & 128 & 128 & 128 & 128 \\
\hline 2 & 256 & 128 & 256 & 128 & 128 & 128 \\
\hline 3 & 256 & 128 & 128 & 64 & 128 & 128 \\
\hline 4 & 512 & 256 & 256 & 256 & 256 & 256 \\
\hline 5 & 256 & 128 & 64 & 64 & 128 & 64 \\
\hline 6 & 256 & 128 & 256 & 128 & 128 & 128 \\
\hline 7 & 256 & 128 & 128 & 64 & 128 & 128 \\
\hline 8 & 256 & 128 & 128 & 128 & 128 & 128 \\
\hline 9 & 256 & 128 & 256 & 256 & 256 & 128 \\
\hline 10 & 256 & 128 & 128 & 128 & 128 & 128 \\
\hline 11 & 256 & 128 & 512 & 256 & 256 & 128 \\
\hline 12 & 512 & 128 & 256 & 128 & 128 & 128 \\
\hline 13 & 512 & 128 & 256 & 256 & 128 & 128 \\
\hline 14 & 512 & 256 & 512 & 256 & 256 & 256 \\
\hline 15 & 512 & 256 & 512 & 256 & 128 & 256 \\
\hline 16 & 512 & 256 & 512 & 256 & 256 & 128 \\
\hline 17 & 512 & 128 & 512 & 256 & 256 & 256 \\
\hline 18 & 256 & 128 & 256 & 256 & 128 & 128 \\
\hline 19 & 256 & 64 & 64 & 256 & 128 & 128 \\
\hline 20 & 256 & 128 & 128 & 128 & 128 & 128 \\
\hline 21 & 256 & 128 & 256 & 256 & 128 & 128 \\
\hline 22 & 512 & 64 & 128 & 32 & 64 & 128 \\
\hline 23 & 512 & 256 & 256 & 64 & 256 & 128 \\
\hline 24 & 512 & 256 & 64 & 32 & 256 & 128 \\
\hline 25 & - & 512 & - & 256 & - & 256 \\
\hline 26 & - & 512 & 512 & 64 & 64 & 128 \\
\hline Ampicillin & NT & NT & 0.3 & 1 & 6 & NT \\
\hline Ofloxacin & 1 & 8 & NT & NT & NT & NT \\
\hline Fluconazole & NT & NT & NT & NT & NT & 1 \\
\hline
\end{tabular}

NT: Not tested, MIC: Minimum inhibitory concentration, -: Represents no activity

(pyrazolines) generally did not appear to make a large difference in antimicrobial effect. Compounds 5, 19, and 24 exhibited the highest antibacterial activity against $S$. aureus, with a MIC value of $64 \mu \mathrm{g} / \mathrm{mL}$ among the tested bacteria. Compounds 19 and 22 were found to have the best activity against $P$. aeruginosa. Compounds 22 and 26 showed the best activity against $B$. subtilis, with a MIC value of $64 \mu \mathrm{g} / \mathrm{mL}$. Compounds 22 and 24 exhibited the highest antimicrobial activity against $E$. faecalis, with a MIC value of $32 \mu \mathrm{g} / \mathrm{mL}$. Compound 5 was found the most active compound against C. albicans, with a MIC value of $64 \mu \mathrm{g} /$ $\mathrm{mL}$. 
Karad et al. ${ }^{24}$ synthesized (2-morpholinoquinolin-3-yl)4,5-dihydro-1H-pyrazol-1-yl) derivatives and studied their antibacterial activity. They found that the existence of $-\mathrm{OCH}_{3}$ substituent at position- 4 in the phenyl ring at the $\mathrm{C}-3$ position in the pyrazoline scaffold enhanced the antibacterial activity and antimalarial potency. For our compounds, a methoxy substituent in this position increased the antibacterial activity against $S$. aureus and $E$. faecalis, when it had bromo at the $\mathrm{R}^{7}$ position and pyridin-4-yl at the $\mathrm{R}^{8}$ position (compound 24 ).

Replacement of 4-methyl with 4-bromo substitution on the $B$ ring in the pyrazoline nucleus enhanced the activity against $S$. aureus and E. faecalis (compounds 23 and 24).
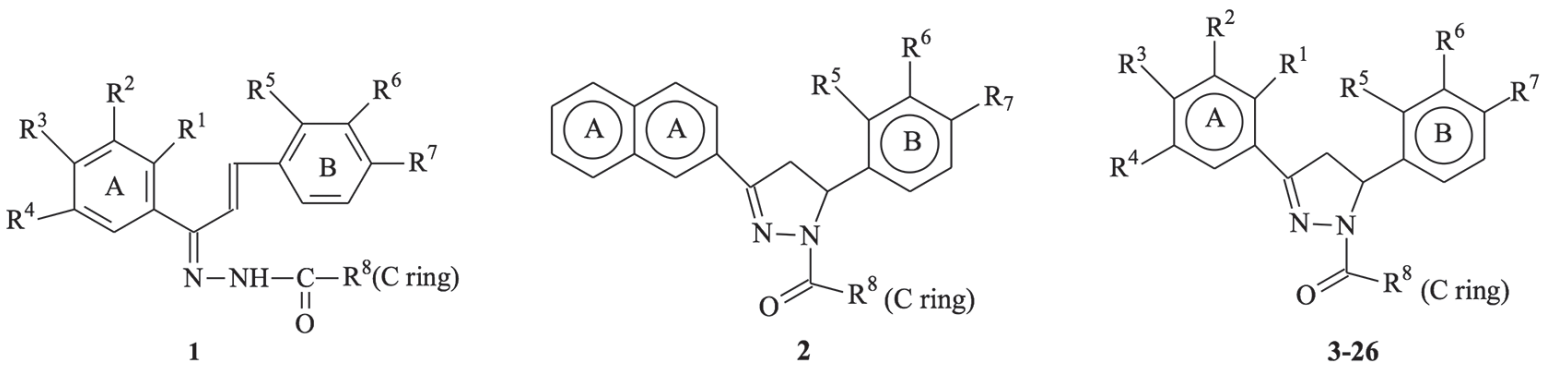

Figure 1. Structures of compounds 1-26

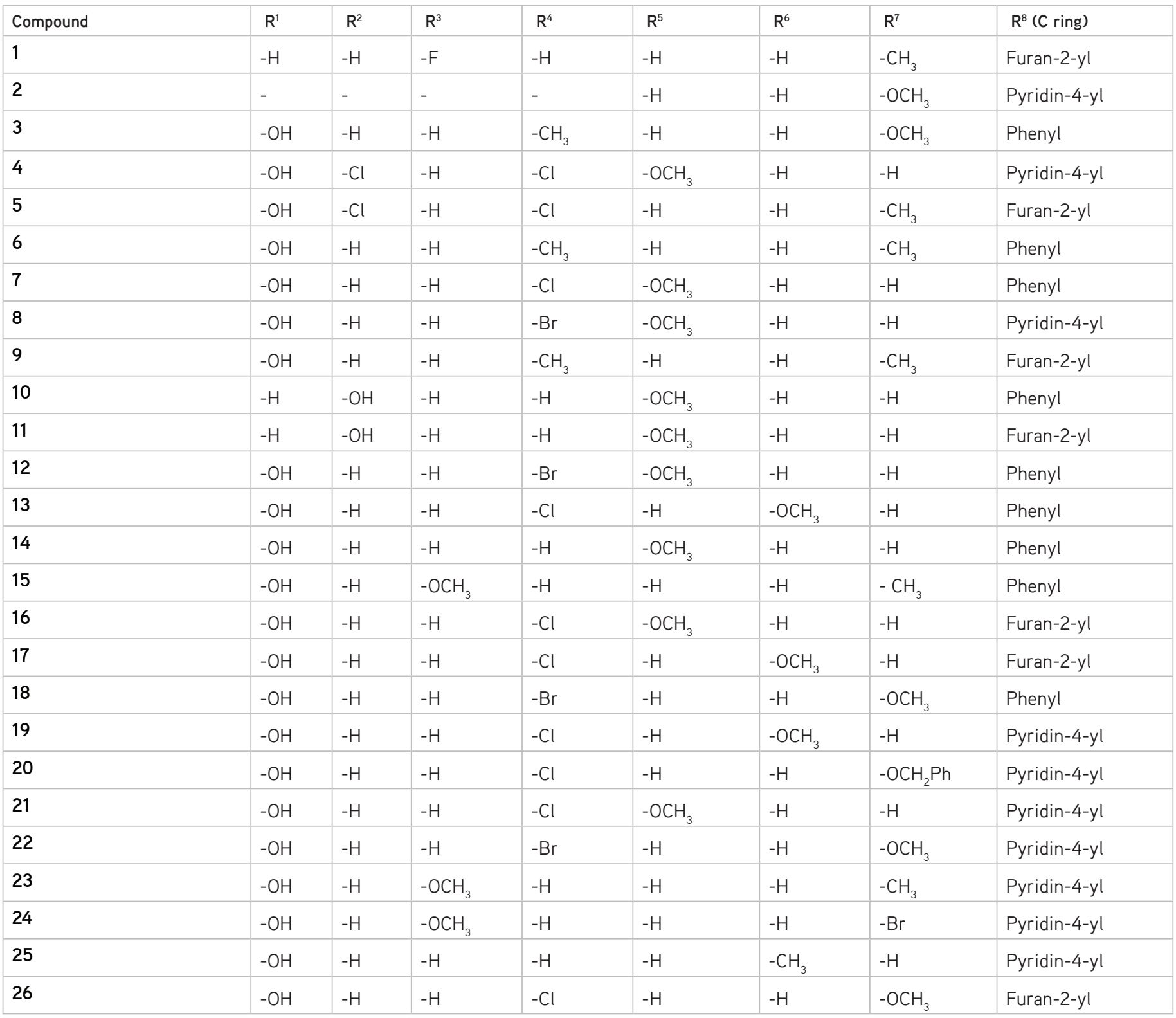


According to Hamada and Abdo, ${ }^{9}$ the addition of pharmacophores such as chloro and bromo substituents with lipophilic properties increased the antimicrobial activity. For our compounds 7,12 , and 14 , the substitution of chloro and bromo atoms at the 5 -position of the $A$ ring tended to increase the biological activity.

When the $C$ ring had a phenyl scaffold, replacement of the 2-hydroxy-5-bromo phenyl (A ring) by 2-hydroxy-5-chloro phenyl increased the antibacterial activity against $E$. coli, $S$. aureus, and E. faecalis (compounds 7 and 12). When the compound carried a pyridine as the $C$ ring, the substitution of 2-hydroxy-3,5-dichloro phenyl decreased the antimicrobial and antifungal activity. Replacement of this group by 2-hydroxy-5bromo phenyl enhanced the antimicrobial activity against all bacteria and the fungus (compounds 4 and 8 ). Replacement of 2-hydroxy-3,5-dichloro phenyl by 2-hydroxy-5-chloro phenyl increased the activity against $E$. coli, $P$. aeruginosa, $B$. subtilis, and $C$. albicans (compounds 4 and 21).

The addition of the naphthyl group instead of phenyl on the $A$ ring in compound 2 resulted in increased efficacy against $E$. coli. It reduced the activity against $S$. aureus, $P$. aeruginosa, $E$. faecalis, and $B$. subtilis. Compound 25 showed no antimicrobial activity against $E$. coli, S. aureus, or B. subtilis. Compound 26 showed no antimicrobial activity against $E$. coli.

Addition of phenyl instead of 2 -furyl as the $\mathrm{C}$ ring increased the activity (compounds 6 and 9; compounds 10 and 11; compounds 13 and 17; compounds 7 and 16). The presence of phenyl instead of pyridine as the $C$ ring increased the antimicrobial activity against $E$. coli. However, addition of pyridine instead of phenyl as the $C$ ring enhanced the antibacterial activity against $S$. aureus, $P$. aeruginosa, E. faecalis, and B. subtilis (compounds 18 and 22). The substitution by a methoxy group at the fourth position on the $B$ ring produced comparable antimicrobial activity against $S$. aureus and $E$. faecalis to the substitution by a methyl group (compounds 3 and 9).

Meta methoxy substitution on the B ring increased the activity against $P$. aeruginosa and $S$. aureus in the presence of pyridine as the $C$ ring (compounds 19 and 21). Para methoxy substitution on the $B$ ring enhanced the antimicrobial activity against $P$. aeruginosa, $E$. faecalis, and $B$. subtilis in the case of a pyridine substituent at the $R^{8}$ position (compounds 8 and 22). Orto methoxy substitution on the $\mathrm{B}$ ring is not preferable, especially when the $\mathrm{C}$ ring is pyridine. According to Manna and Agrawal ${ }^{25}$ ortho substitution in the phenyl ring with a methoxy group at the $5^{\text {th }}$ position of the pyrazoline ring caused less or inactive antibacterial activity against Gram-negative bacteria.

Replacement of 5-bromo with 5-methyl substitution on the A ring enhanced the activity against $S$. aureus and $E$. faecalis (compounds 3 and 18).

The presence of a methyl group at the fifth position of the $A$ ring instead of a methoxy group at the fourth position of the $A$ ring increased the antifungal activity and antimicrobial activity against $E$. coli, S. aureus, E. faecalis, $P$. aeruginosa, and $C$. albicans (compounds 6 and 15).

\section{CONCLUSION}

In this work, several pyrazoline derivatives and one hydrazone derivative were synthesized and screened for their antibacterial and antifungal activities. We noted that the pyridine ring as the $C$ ring and methoxy and bromo substitutions on the $B$ ring are preferable for a good antibacterial effect. 2-hydroxy-5chloro substitution and 2-hydroxy-4-methoxy substitution substituents are favorable as the A ring. Further studies are necessary in order to understand the relation between the substitutions and activity, which could guide the design of more potent antimicrobial agents for therapeutic use.

\section{ACKNOWLEDGEMENTS}

I would like to thank to the staff of the Central Laboratory of the Pharmacy Faculty of Ankara University for the acquisition of the nuclear magnetic resonance mass spectrometer, and elemental analyzer of this work.

Conflicts of interest: No conflict of interest was declared by the authors. The authors alone are responsible for the content and writing of the paper.

\section{REFERENCES}

1. Ventola CL. The antibiotic resistance crisis, part 1: causes and threats, PT. 2015;40:277-283.

2. Wernli D, Jørgensen PS, Harbarth S, Carroll SP, Laxminarayan R, Levrat N, Rottingen JA, Pittet D. Antimicrobial resistance: The complex challenge of measurement to inform policy and the public. PLoS Med. 2017;14:e1002378.

3. He J, Jia X, Yang S, Xu X, Sun K, Li C, Yang T, Zhang L. Heteroresistance to carbapenems in invasive Pseudomonas aeruginosa infections. Int $J$ Antimicrob Agents. 2018;51:413-421.

4. Luo K, Shao F, Kamara KN, Chen S, Zhang R, Duan G, Yang H. Molecular characteristics of antimicrobial resistance and virulence determinants of Staphylococcus aureus isolates derived from clinical infection and food. J Clin Lab Anal. 2018;e22456.

5. Raiford LC, Davis HL. Condensation products of benzalacetophenone and some of its derivatives. J Am Chem Soc. 1928;50:156-162.

6. Pimenov AA, Makarova NV, Moiseev IK, Zemtsova MN. Interaction of $\alpha, \beta$ unsaturated ketones of the adamantane series with $\mathrm{N}, \mathrm{N}^{\prime}$-binucleophiles. Chem Heterocycl Compd. 2004;40:575-581.

7. Rollas S, Küçükgüzel ȘG. Biological activities of hydrazone derivatives. Molecules. 2007;12:1910-1939.

8. Gökhan-Kelekçi N, Koyunoglu S, Yabanoglu S, Yelekçi K, Özgen Ö, Uçar G, Erol K, Kendi E, Yesilada A. New pyrazoline bearing $4(3 \mathrm{H})$-quinazolinone inhibitors of monoamine oxidase: synthesis, biological evaluation, and structural determinants of MAO-A and MAO-B selectivity. Bioorg Med Chem. 2009;17:675-689.

9. Hamada NM, Abdo NY. Synthesis, characterization, antimicrobia screening and free-radical scavenging activity of some novel substituted pyrazoles. Molecules. 2015;20:10468-10486.

10. Evranos Aksoz B, Ucar G, Yelekçi K. Design, synthesis and hMAO inhibitory screening of novel 2-pyrazoline analogues hMAO inhibitory screening of novel 2-pyrazolines. Comb Chem High Throughput Screen. 2017;20:510-521. 
11. Sahu SK, Banerjee M, Samantray A, Behera C, Azam MA. Synthesis, analgesic, anti-inflammatory and antimicrobial activities of some novel pyrazoline derivatives. Trop J Pharm Res. 2008;7:961-968.

12. Yusuf $M$, Jain P. Synthetic and biological studies of pyrazolines and related heterocyclic compounds. Arab J Chem. 2014;7:553-596.

13. Evranos Aksoz B, Ucar G, Taş ST, Aksoz E, Yelekci K, Erikci A, Sara Y, Iskit AB. New hMAO-A inhibitors with potential antidepressant activity: design, synthesis, biological screening and evaluation of pharmacological activity. Comb Chem High Throughput Screen. 2017;20:461-473.

14. Clinical and Laboratory Standards Institute. Methods for dilution antimicrobial susceptibility tests for bacteria that grow aerobically. Approved Standard. In: CLSI Publication M 07-A8, 8th ed., CLSI; Wayne, PA, USA, 2009.

15. European Committe on Antimicrobial Susceptibility Testing (EUCAST). Breakpoint tablets for interpretation of MICs and zone diameters. Version 3.1., Last Accessed Date: 11.02.2013 Available from: https://eucast.org/

16. Zhao LM, Jin HS, Sun LP, Piao HR, Quan ZS. Synthesis and evaluation of antiplatelet activity of trihydroxychalcone derivatives. Bioorg Med Chem Lett. 2005;15:5027-5029.

17. Boeck P, Falcao CAB, Leal PC, Yunes RA, Filho VC, Torres-Santos EC, Rossi-Bergmann B. Synthesis of chalcone analogues with increased antileishmanial activity. Bioorg Med Chem. 2006;14:1538-1545.

18. Jun $N$, Hong $G$, Jun $K$. Synthesis and evalution of $2^{\prime}, 4^{\prime}, 6^{\prime}$-trihydroxychalcones as a new class of tyrosine inhibitors. Trihydroxychalcones as a new class of tyrosine inhibitors. Bioorg Med Chem. 2007;15:2396-2402.
19. Forghieri M, Laggner C, Paoli P, Langer T, Manao G, Camici G, Bondioli $L$, Prati $F$, Costantino L. Synthesis, activity and molecular modeling of a new series of chromones as low molecular weight protein tyrosine phosphatase inhibitors. Bioorg Med Chem. 2009;17:2658-2672.

20. De Meyer ND, Haemers A, Mishra L, Pandey HK, Pieters LAC, Berghe DAV, Vlietinck AJ. 4'-Hydroxy-3-methoxyflavones with potent antipicornavirus activity. J Med Chem. 1991;34:736-746.

21. Hozien ZA. Synthesis of some new heterocyclic systems derived from 2- acetylbenzimidazole. J Chem Tech Biotechnol. 1993;57:335-341.

22. Prasad YR, Rao AL, Prasoona L, Murali K, Kumar PR. Synthesis and antidepressant activity of some 1,3,5-triphenyl-2-yrazolines and 3-(2"-hydroxy naphthalen-1"-yl)-1,5-diphenyl-2-pyrazolines. Bioorg Med Chem Lett. 2005;15:5030-5034.

23. Ali MA, Shaharyar M, Siddiqui AA. Synthesis, structural activity relationship and anti-tubercular activity of novel pyrazoline derivatives. Eur J Med Chem. 2007;42:268-275.

24. Karad SC, Purohit VB, Thakor P, Thakkar VR, Raval DK. Novel morpholinoquinoline nucleus clubbed with pyrazoline scaffolds: synthesis, antibacterial, antitubercular and antimalarial activities. Eur J Med Chem. 2016;112:270-279.

25. Manna K, Agrawal YK. Microwave assisted synthesis of new indophenazine 1,3,5-trisubstiuted pyrazoline derivatives of benzofuran and their antimicrobial activity. Bioorg Med Chem Lett. 2009;19:26882692. 